\title{
Characteristic Description of Hospitalized Bipolar Affective Disorder Patients
}

\author{
Muhammad Adam Zulqarnain* \\ Faculty of Medicine \\ Jenderal Achmad Yani University \\ Cimahi, Indonesia \\ *adam.zulqarnain77@gmail.com
}

\author{
Lukas Kabul Budianto, Chatidjah Satrijo Wibowo \\ Department of Psychiatric \\ Jenderal Achmad Yani University \\ Cimahi, Indonesia
}

\begin{abstract}
Bipolar disorder was a severe mental disorder that had a quite high prevalence of around 1-2\%, with multifactorial etiology. Most patients had a chronic symptom of bipolar disorder. The chronicity of symptoms caused comorbidities that could eventually cause malfunction and death. This study aimed to describe the characteristics description of patients with bipolar affective disorder which hospitalized in the Psychiatric Hospital of West Java Province. The research method was descriptive with a sample of 375 data from 499 medical records. Data were collected through the medical record section in the Psychiatric Hospital of West Java Province and the results were presented in the form of a frequency distribution table. From the result of this study found that the count of bipolar affective disorder patients which hospitalized in the Psychiatric Hospital of West Java Province were mostly in the age of 20-29 years as much as 117 people $(31.2 \%)$, with male gender as much as 212 people $(56.5 \%)$, and did not have a family history of mental disorder as much as 261 people $(69.6 \%)$, marital status more in patients who were single as much as 170 people $(\mathbf{4 5 . 3 \%})$, for the homeland were more from rural people as much as 268 people $(71.5 \%)$, while the most job were in patients who unemployed as much as 272 people $(72.5 \%)$, and in the level of education most cases were at high school as much as 128 people $(34.1 \%)$.
\end{abstract}

Keywords—affective disorder, bipolar disorder, characteristics

\section{INTRODUCTION}

Mood disorders (affective or mood disorders) are a group of clinical features characterized by reduced or lost emotional control and self-control. Affective disorders can be in the form of depressive symptoms, manic symptoms, or a mixture of the two (bipolar) [1,2]. Bipolar disorder is a serious mental disorder with a fairly high prevalence of $1-2 \%$, with multifactorial etiology [3]. Most of the patients have chronic symptoms of bipolar disorder. The chronicity of these symptoms causes comorbidities that can eventually lead to dysfunction and death. The bipolar affective disorder is a common condition, and among mental disorders, it is the second largest cause of disability $[3,4]$.

The bipolar disorder begins to appear in adolescence and continues throughout life [5]. Based on observations made in the United States, the number of children and adolescents experiencing this disorder increased by $40 \%$ from 1994-2003 and is predicted to continue to increase every year [6]. This is most likely due to an unpleasant childhood history such as experiencing a lot of anxiety or depression. Abuse of alcohol, drugs, and other illnesses can also lead to the emergence of bipolar disorder in childhood and adolescence [7-9]. Therefore, early diagnosis is very important so that this disorder can be followed up appropriately and does not endanger the patient or the people around them $[5,6]$.

Complications from bipolar disorder are quite complex and severely disrupt a personal social function until the most fatal is suicide $[10,11]$. Bipolar depressed patients can experience suicide 15 times more than the general population [4]. According to the results of Pardede's research in 2012, it was found that $69 \%$ of cases of suicide attempts were carried out by the productive age group, namely 15-29 years with a total of 80 cases. It can be concluded that the young adult age group is very susceptible to depression. The highest proportion of perpetrators of suicide attempts was found to be $62.9 \%$ of people who have psychotic disorders or are diagnosed with mental health disorders such as major depression, anxiety disorders and the most dominant is bipolar disorder $[5,12]$.

Based on the USA Government's National Institute of Mental Health (NIMH), bipolar disorder is not only caused by a single factor, but by many factors that collectively trigger the formation of this disorder. Because of the many factors involved, bipolar disorder is also known as a multi-factor disorder. Among them are genetic and environmental factors that involve relationships between individuals or events to achieve goals (reward) in life. Environmental factors include the social environment which has a large enough influence $[7,8]$.

Based on genetic factors, bipolar disorder tends to pass down to generations, the first offspring of someone with bipolar disorder is at 7 times more likely to experience a similar disorder [9]. Based on environmental factors, bipolar disorder is more common in people who are divorced and live alone than in married people $[9,13]$. Bipolar disorder is also more common in people who do not graduate from school and lose their jobs or are unemployed [9]. By region of origin, the 
prevalence of depression is more common in people who come from rural areas than in people who come from urban areas. This is probably due to its relation to work and education level [9].

In bipolar disorder, manic episodes are more frequent in males, whereas depressive episodes are more frequent in females. The reasons for differences that have been investigated involve hormonal differences and differences in psychosocial stressors [9]. The prevalence of depressive disorders in the world's population is mostly at the productive age, namely 20-50 years [8]. The incidence of major depressive disorder may increase in people younger than 20 years due to increased alcohol use and other substances at that age [9].

Several studies describe the characteristics of patients with bipolar affective disorder. One of them is the research of Syafwan et al. in patients with a bipolar affective disorder in the inpatient department of RSJ Prof. Dr. HB. Sa'anin Padang in 2010-2011. From the research of Syafwan et al., it was found that the most age was 20-29 years old, based on gender, it was found that the prevalence of men was greater than women, the most marital status was in unmarried patients, for occupations the most were patients who did not work, while regarding patient education, it was found that Most of them are in Senior High School - equivalent [14].

The West Java Province Mental Hospital is a special type A hospital that provides promotional, preventive, curative, and rehabilitative services as well as being a referral center and a place for research in the development of health science and technology. According to data from the medical records of the Mental Hospital of West Java Province, the number of hospitalized bipolar affective disorder patients in 2014 were 201 people, and in 2015 were 298 people.

Based on the problems described above, the researcher was interested in researching on "Characteristic Description of Hospitalized Bipolar Disorders Patients at the Mental Hospital of West Java Province".

\section{METHODS}

This research was conducted with a descriptive research design in the Mental Hospital of West Java Province. The number of samples taken in this study were 375 medical records of inpatients diagnosed with the bipolar affective disorder in 2014-2015. Sampling using consecutive sampling. Taking steps, namely from all existing medical records of patients with bipolar affective disorder, first see whether the patient has organic mental disorders or not. If the patient has an organic mental disorder then data is not collected. After that, it is seen from the completeness of medical record data consisting of age, gender, family history, marital status, area of origin, occupation, and patient education. If the medical record data is incomplete then it is not taken. After that, the data were processed manually and grouped by age, gender, family history, marital status, area of origin, occupation, and patient education. Then the data is presented in the form of a frequency distribution table. Data analysis was carried out descriptively using Microsoft Excel.

\section{RESULTS AND DISCUSSION}

Research data collection has been carried out in the inpatient section of the Mental Hospital of West Java Province from 17 January 2017 to 27 January 2017. In this study, the sample size was 499 samples, of which 375 were included in the inclusion criteria, consisting of 149 hospitalized patients with a bipolar affective disorder in 2014 and 226 hospitalized patients with bipolar affective a disorder in 2015 .

TABLE I. DESCRIPTION AND CHARACTERISTICS OF PATIENTS WITH BIPOLAR AFFECTIVE DISORDER BY AGE

\begin{tabular}{|l|l|l|}
\hline \multicolumn{1}{|c|}{ Age range } & \multicolumn{2}{c|}{ Total } \\
\cline { 2 - 3 } & \multicolumn{1}{|c|}{ Amount } & \multicolumn{1}{c|}{ Percentage } \\
\hline$<20$ years & 22 & 5.9 \\
\hline 20-29 years & 117 & 31.2 \\
\hline $30-39$ years & 115 & 30.7 \\
\hline $40-49$ years & 77 & 20.5 \\
\hline $50-59$ years & 38 & 10.1 \\
\hline 60 years & 6 & 1.6 \\
\hline Total & $\mathbf{3 7 5}$ & $\mathbf{1 0 0}$ \\
\hline
\end{tabular}

Based on Table 1, it was found that the most inpatients who experienced bipolar affective disorder were in the age range of 20-29 years as many as 49 people (32.9\%), while in 2015 the most were in the $30-39$ year age range. 72 people $(31.9 \%)$, and overall from 2014-2015, the highest number of patients was at the age of $20-29$ years as many as 117 people $(31.2 \%)$. While the lowest results from 2014-2015 were at the age of more or equal to 60 with a total of 4 people in 2014 (2.7\%), in 2015 as many as 2 people $(0.9 \%)$, and from 2014-2015. as many as 6 people $(1.6 \%)$. Patients aged less than 20 years experienced a significant increase, namely 2.7 times from 2014 to 2015. This is likely due to the increasing use of alcohol and other substances at that age [9].

Similar results were obtained from the research of Syafwan et al. In the research of Syafwan et al. It was found that the highest age was found in inpatients who experienced bipolar affective disorder at RSJ Prof. Dr. HB. Sa'anin Padang in 20102011 was 20-29 years old, which was $42.2 \%$ in 2010 and $36.6 \%$ in 2011 . Then the second highest age after that was 3039 years, which was 30.2. \% in 2010 and $33.2 \%$ in 2011 . Forage three, the highest proportion was 40 - 49 years, which was $15.6 \%$ in 2010 and 2011 [14]. The results of this study are following the prevalence of depressive disorders in the world's population, the highest in productive age, namely $20-50$ years [8]. 
TABLE II. DESCRIPTION AND CHARACTERISTICS OF PATIENTS WITH BIPOLAR AFFECTIVE DISORDER BY GENDER

\begin{tabular}{|c|c|c|}
\hline \multirow[t]{2}{*}{ Gender } & \multicolumn{2}{|r|}{ Total } \\
\hline & Amount & Percentage \\
\hline Male & 212 & 56.5 \\
\hline Female & 163 & 43.5 \\
\hline Total & 375 & 100 \\
\hline
\end{tabular}

Based on Table 2, it was found that the sex of bipolar affective disorder patients who were hospitalized at the Mental Hospital of West Java Province in 2014-2015 was more male than female. The number of men who experienced bipolar affective disorder in the inpatient department in 2014 was 76 people $(51.0 \%)$, while in 2015 there were 136 people $(60.2 \%)$, and overall from $2014-2015$ as many as 212 people (56.5\%).

The results of research by Syafwan et al. The same results were obtained for the gender of inpatients with the bipolar affective disorder at RSJ Prof. Dr. HB. Sa'anin Padang in 20102011. In the study of Syafwan et al., The prevalence of males was greater than females, namely as much as $75.4 \%$ in 2010 and $73.7 \%$ in 2011 [14]. According to Kaplan and Sadock, manic episodes were more frequent in males, and depressive episodes were more frequent [9]. Meanwhile, according to Vieta, bipolar disorder in women and men is the same [15]. The reasons for the differences that have been investigated involve hormonal differences and differences in psychosocial stressors for men and women [9].

TABLE III. DESCRIPTION AND CHARACTERISTICS OF PATIENTS WITH BIPOLAR AFFECTIVE DISORDER BY FAMILY HISTORY OF MENTAL DiSORDER

\begin{tabular}{|c|c|c|}
\hline \multirow[t]{2}{*}{ Family History } & \multicolumn{2}{|r|}{ Total } \\
\hline & Amount & Percentage \\
\hline Exist & 114 & 30.4 \\
\hline Not exist & 261 & 69.6 \\
\hline Total & 375 & 100 \\
\hline
\end{tabular}

Based on Table 3, it can be seen that the number of bipolar affective disorder patients who were hospitalized at the Mental Hospital of West Java Province in 2014-2015 based on the family history of patients with mental disorders. In 2014 and 2015 , it was found that more patients did not have a family history of mental disorders than those who had a family history of mental disorders. In 2014, the number of patients with a family history of mental disorders was 38 people $(25.5 \%)$ and 111 people without a family history of mental disorders (74.5\%). Meanwhile, in 2015, the number of patients who had a family history of mental disorders was 76 people $(33.6 \%)$ and those who did not have a family history of mental disorders were 150 people $(66.4 \%)$. Overall, from $2014-2015$, there were 114 patients $(30.4 \%)$ who had a family history of mental disorders and $261(69.6 \%)$ who did not have a family history of mental disorders.

Based on the results obtained above, family history factors influenced the occurrence of bipolar affective disorder by $30.4 \%$ of bipolar affective disorder patients in the inpatient department of the Mental Hospital in West Java Province in 2014-2015. According to Kaplan and Sadock, 50\% of bipolar patients have one parent with a mood disorder / affective disorder, most often unipolar (depression alone). If one parent has bipolar disorder, $27 \%$ of the child is at risk of developing a mood disorder. If both parents have bipolar disorder, $75 \%$ of their children are at risk of developing a mood disorder. The first offspring of someone with bipolar disorder is at 7 times more likely to experience the disorder. Even the risk of twins is very high, especially in monozygous twins (40-80\%), while dizygotic twins are lower, namely $10-20 \%$. which locus of the chromosome is actually involved [16].

TABLE IV. DESCRIPTION AND CHARACTERISTICS OF PATIENTS WITH BIPOLAR AFFECTIVE DISORDER BY MARITAL STATUS

\begin{tabular}{|l|l|l|}
\hline \multirow{2}{*}{ Marital status } & \multicolumn{2}{c|}{ Total } \\
\cline { 2 - 3 } & \multicolumn{1}{|c|}{ Amount } & \multicolumn{1}{c|}{ Percentage } \\
\hline Single & 170 & 45.3 \\
\hline Married & 131 & 34.9 \\
\hline Divorce & 74 & 19.7 \\
\hline Total & $\mathbf{3 7 5}$ & $\mathbf{1 0 0}$ \\
\hline
\end{tabular}

Based on Table 4, it was found that the marital status of bipolar affective disorder patients who were hospitalized at the Mental Hospital of West Java Province in 2014-2015, was mostly unmarried patients. The number of unmarried patients in 2014 was 62 people $(41.6 \%)$, while in 2015 there were 108 people $(47.8 \%)$, and overall from 2014-2015 there were 170 people $(45.3 \%)$

In the research of Syafwan et al. of inpatients who experience the bipolar affective disorder at RSJ Prof. Dr. HB. Sa'anin Padang in 2010-2011 obtained similar results in the highest prevalence based on marital status, which was found in unmarried patients as much as $58.8 \%$ in 2010 and $54.6 \%$ in 2011, while the lowest frequency was found in patients. Who divorced were $2.5 \%$ in 2010 and $2.8 \%$ in 2011 [14]. These results are consistent with Kaplan and Sadock, namely that bipolar disorder is found mostly in people who are divorced and live alone or unmarried [9].

TABLE V. DESCRIPTION AND CHARACTERISTICS OF PATIENTS WITH BIPOLAR AFFECTIVE DISORDER BY HOMELAND

\begin{tabular}{|c|c|c|}
\hline \multirow[t]{2}{*}{ Homeland } & \multicolumn{2}{|r|}{ Total } \\
\hline & Amount & Percentage \\
\hline Rural & 268 & 71.5 \\
\hline Urban & 107 & 28.5 \\
\hline Total & 375 & 100 \\
\hline
\end{tabular}

Based on Table 5, it is found that the area of origin of bipolar affective disorder patients who were hospitalized at the Mental Hospital of West Java Province in 2014-2015 came more from rural areas compared to urban areas. The number of patients from rural areas in 2014 was 102 people $(68.5 \%)$, while in 2015 there were 166 people $(73.5 \%)$, and as a whole from $2014-2015$ there were 268 people $(71.5 \%)$. 
The results obtained based on the area of origin are following Kaplan and Sadock, namely, depression is more common in people who come from rural areas than people who come from urban areas. This is probably because it is related to the work and educational level of people who come from rural areas, which are different from those of people who come from urban areas [9].

TABLE VI. DESCRIPTION AND CHARACTERISTICS OF PATIENTS WITH BIPOLAR AFFECTIVE DISORDER BY JOB

\begin{tabular}{|l|l|l|}
\hline \multirow{2}{*}{ Job } & \multicolumn{2}{c|}{ Total } \\
\cline { 2 - 3 } & \multicolumn{1}{|c|}{ Amount } & \multicolumn{1}{c|}{ Percentage } \\
\hline Laborer & 15 & 4.0 \\
\hline Civil Servant & 6 & 1.6 \\
\hline Soldier or Police & 3 & 0.8 \\
\hline Farmer & 7 & 1.9 \\
\hline Entrepreneur & 34 & 9.1 \\
\hline College Student & 5 & 1.3 \\
\hline Student & 8 & 2.1 \\
\hline Housewife & 25 & 6.7 \\
\hline Unemployed & 272 & 72.5 \\
\hline Total & $\mathbf{3 7 5}$ & $\mathbf{1 0 0}$ \\
\hline
\end{tabular}

Based on Table 6, it was found that the occupation of bipolar affective disorder patients who were hospitalized at the Mental Hospital of West Java Province in 2014-2015 was mostly in patients who did not work. The number of patients who did not work in 2014 was 106 people (71.1\%), while in 2015 there were 166 people (73.4\%), and overall from 2014201,5 there were 272 people $(72.5 \%)$.

The research results of Syafwan et al. obtained the appropriate results regarding the occupation of bipolar affective disorder patients in the inpatient department of RSJ Prof. HB. Sa'anin Padang is most patients who do not work, as many as $80.9 \%$ in 2010 and $76.1 \%$ in 2011 [14]. These results are consistent with Kaplan and Shaddock that bipolar disorder is more often found in people who lose their jobs or are unemployed [9].

TABLE VII. DESCRIPTION AND CHARACTERISTICS OF PATIENTS WITH BIPOLAR AFFECTIVE DISORDER BY EDUCATION LEVEL

\begin{tabular}{|l|l|l|}
\hline \multirow{2}{*}{ Education Level } & \multicolumn{2}{c|}{ Total } \\
\cline { 2 - 3 } & \multicolumn{1}{|c|}{ Amount } & \multicolumn{1}{c|}{ Percentage } \\
\hline Magister & 1 & 0.3 \\
\hline Bachelor & 24 & 6.4 \\
\hline Diploma & 13 & 3.5 \\
\hline High School & 128 & 34.1 \\
\hline Junior High School & 97 & 25.8 \\
\hline Elementary School & 109 & 29.1 \\
\hline No School & 3 & 0.8 \\
\hline Total & $\mathbf{3 7 5}$ & $\mathbf{1 0 0}$ \\
\hline
\end{tabular}

Based on Table 7, it was found that most patients with the bipolar affective disorder who were hospitalized in the Mental Hospital of West Java Province in 2014-2015 were at the senior high school level. The number of patients with education up to senior high school-equivalent in 2014 was 55 people
(36.9\%), while in 2015 there were 73 people (32.3\%), and overall from 2014-2015 128 people (34.1\%).

The same results were obtained in the study of Syafwan et al. According to the research results of Syafwan et al. regarding the education of bipolar affective disorder patients in the inpatient department of RSJ Prof. HB. The highest number of Sa'anin Padang was found in senior high school (high schoolequivalent), namely, as much as $43.2 \%$ in 2010 and $41.5 \%$ in 2011, while the lowest was in patients who did not go to school, namely $1 \%$ in 2010 and $3.8 \%$ in 2011.14 According to Kaplan and Shaddock, the bipolar affective disorder is more common in people who do not graduate from school [9].

\section{CONCLUSION}

Based on the results of the study, the number of bipolar affective disorder patients which hospitalized in the Psychiatric Hospital of West Java Province were mostly in the age of 2029 years as much as 117 people $(31.2 \%)$, with male gender as much as 212 people $(56.5 \%)$, and did not have a family history of mental disorder as much as 261 people $(69.6 \%)$, marital status more in patients who were single as much as 170 people $(45.3 \%)$, for the homeland were more from rural people as much as 268 people $(71.5 \%)$, while the most job were in patients who unemployed as much as 272 people $(72.5 \%)$, and in the level of education, most cases were at high school as much as 128 people $(34.1 \%)$.

Need further research on the relationship between the variables studied and the occurrence of bipolar affective disorder.

\section{REFERENCES}

[1] R. Maslim, Buku saku Diagnosis gangguan jiwa rujukan ringkas dari PPDGJ III. Jakarta: Bagian Ilmu Kedokteran Jiwa FK Unika Atmajaya 2001.

[2] N. Amir, Depresi aspek neurobiologi diagnosis dan tatalaksana. Jakarta: Badan Penerbit Fakultas Kedokteran Indonesia, 2005.

[3] N. Amir, Gangguan mood bipolar: kriteria diagnostik dan tatalaksana dengan obat antipsikotika atipik. Jakarta: Badan Penerbit Fakultas Kedokteran Universitas Indonesia, 2007.

[4] R. Widiodiningrat, "Membangun Kesadaran-Mengurangi Resiko gangguan Mental dan Bunuh Diri," 2010. [Online]. Retrieved from http://pdpersi.co.id [Accessed on: 28 July 2016].

[5] S.U. Veronica, "Bipolar disorder bisa dikendalikan," 2011 [Online]. Retrieved from: http://www.nirmalamagazine.com/articles/viewArticleCategory/35/page: 6 [Accessed on: 28 June 2016].

[6] D.Z. Lieberman, G. Kolodner, S.H. Massey, and K.P. Williams, "Antidepressant-induced mania with concomitant mood stabilizer in patients with comorbid substance abuse and bipolar disorder," Journal of addictive diseases, vol. 28, no. (4), pp. 348-355, 2009.

[7] National Institute Mental Health (NIMH) Journal, Bipolar Disorder. New York: NIMH, 2012.

[8] I.M. Wiguna, Sinopsis psikiatri, jilid 1. Tangerang: Binarupa Aksara Publisher, 2010 
[9] B.J. Sadock and V.A. Sadock, Kaplan \& Sadock's Synopsis of Psychiatric, 10th edition. Philadelphia: Lippincott Williams and Wilkins, 2007.

[10] WHO, Mental Health Journals: Bipolar Disorder. Washington DC: WHO Publications, 2013.

[11] N. Hoeksema, A Psychometric Analysis. Yale: Yale University Press, 2011, p. 14.

[12] C.M. Pardede, "Karakteristik penderita percobaan bunuh diri dengan racun di Rsud dr. Pirngadi kota Medan tahun 2006-2011," Gizi, Kesehatan Reproduksi dan Epidemiologi, vol. 1, no. (01), p. 8, 2012.
[13] I.M. Wiguna, Sinopsis psikiatri, jilid 2. Tangerang: Binarupa Aksara Publisher, 2010

[14] A.F. Syafwan, K. Sedjahtera, and A. Asterina, "Gambaran Peningkatan Angka Kejadian Gangguan Afektif dengan Gejala Psikotik pada Pasien Rawat Inap di RSJ Prof. Dr. HB. Sa'anin Padang pada Tahun 20102011," Jurnal Kesehatan Andalas, vol. 3, no. (2), 2014.

[15] E. Vieta, Managing Bipolar Disorder in Clinical Practice, 2nd edition. London: Current Medicine Group Ltd, 2009.

[16] H.I. Kaplan, B.J. Sadock, and J.A. Grebb, Sinopsis Psikiatri Ilmu Pengetahuan Perilaku Psikiatri Klinis, Jilid Dua, Edisi ke-7. Jakarta: Binarupa Aksara, 1997, pp. 809-816. 